\title{
Papéis do público na produção de conteúdo digital: um estudo de caso da Folha.com
}

\author{
DaVi de Castro de MagalHães
}

Universidade de Brasília - davidecastro2@gmail.com Bacharel em Jornalismo e Mestrando em Comunicação (Teorias e Tecnologias) na UnB.

\section{Resumo}

Este trabalho visa investigar os papéis que os públicos assumem no contexto do ciberespaço, especificamente na prática do jornalismo on-line da Folha.com. Adotando o método observacional, realizamos um estudo de caso da Folha.com, analisando sua editoria 'Painel do Leitor' e atuação em mídias sociais. A partir da observação, descrevemos e analisamos o material coletado, discutindo e refletindo os papéis desempenhados pelos usuários, os quais foram listados: jornalista amador, fonte, compartilhador e receptor.

\section{Palavras-chave}

Público, jornalismo digital, papéis sociais.

\footnotetext{
Abstract

\section{Keywords}

Public, digital journalism, social role.
}

This article aims to investigate the social roles assumed by the public in cyberspace's context, specifically on online journalism practice on Folha.com. By the observational method, a case study of Folha.com were made, analyzing its section 'Painel do Leitor' and its social media uses. From observation, we described and analyzed the collected data, discussing and reflecting about the roles played by the users: amateur-journalist, source, spreader and receptor.

Artigo recebido em 14/03/2012

Aprovado em 08/04/2012 


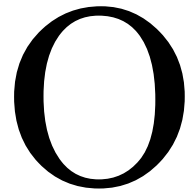

acesso usual, recorrente e em número cada vez maior de dispositivos tecnológicos como notebooks, smartphones e tablets, aliado a formas cada vez mais acessíveis de conexão com a Internet, instaurou condições para diversificados tipos de participação dos sujeitos na vida social. Segundo dados do IBOPE $^{1}$, o total de pessoas com acesso à Internet no Brasil atingiu 77,8 milhões no segundo trimestre de 2011, sendo que 39,3 milhões participam de sites de redes sociais, fóruns, blogs, microblogs e outras páginas de relacionamento, o equivalente a um alcance de $87 \%$ dos internautas. No jornalismo, esse movimento, aliado à "difusão de uma ideologia libertária associada às novas tecnologias" (PEREIRA; ADGHIRNI, 2011, p. 51), se traduz na crescente participação dos públicos nos diferentes tipos de mídia (MORAES, 2010).

À medida que se apropria das novas mídias, estabelecendo novas práticas sociais, o público não só ganha corpo como também voz, elemento essencial para um efetivo processo comunicacional dialógico, regido por um intercâmbio de informações diverso do modelo tradicional de perspectiva puramente técnica. Moraes (2010, p. 1) sintetiza a trajetória e nova condição do público: “Antes restritos ora à posição de meros espectadores, ora a espaços marginais, como 'cartas do leitor' ou 'voz do ouvinte', o público agora sai das zonas de sombra e pode ocupar múltiplos e crescentes lugares”. Os públicos vêm assumindo, nesse entendimento, novos papéis sociais em relação aos veículos de notícia on-line.

Este estudo se propõe a investigar os papéis desempenhados pelo público na produção de conteúdo digital a partir da editoria 'Painel do Leitor' do site de notícias da Folha de S. Paulo, a Folha.com, e sua atuação nas mídias sociais. Deste modo, pretendemos responder aos seguintes questionamentos: a) Como a Folha.com busca explorar as potencialidades do ciberespaço, desenvolvendo estratégias para a participação do público? b) Como o público interage com essas possibilidades?

\section{Dos Públicos do ciberespaço}

Segundo a pesquisadora Moraes (2010), não existem mais apenas emissores e receptores passivos, mas agentes do processo comunicacional. "O caráter massivo de 
outrora cede lugar ao público heterogêneo e segmentado. É sob esta acepção de público que a Internet surge e se concretiza como mídia e tal fator marca as relações comunicativas que vão ser construídas nesse ambiente" (MORAES, 2010, p. 10).

Tredan (2011) considera que o pesquisador deve olhar para o público (internauta) sob o prisma de seu duplo estatuto: leitor e gestor dos espaços de publicação, ou seja, receptor e produtor. "Nesse sentido, parece necessário defini-lo (o público) em um nível mais profundo e a partir de um ponto de vista mais plural" (TREDAN, 2011, p. 5). Dessa forma, não há que se falar em público, mas em públicos, tendo em vista as muitas possibilidades de atuação dos usuários no ciberespaço, favorecidos pelas plataformas que a Internet oferece e suas formas de apropriação. Os usuários atuam de maneira diferente, têm interesses divergentes, portanto, constituem vários públicos, não apenas um, cuja singularidade do termo implicaria em uma supressão de toda a sua diversidade. "O público, de algum modo, não existe: é plural, assim como são múltiplos os objetos a partir dos quais se pretende alcançá-los" (RUELLAN, 2006, p. 35).

\section{Percurso Metodológico}

Como processo formal e sistemático de desenvolvimento deste estudo, adotamos a pesquisa de caráter exploratório, que tem intuito de proporcionar visão geral, do tipo aproximativo, acerca de determinado fato. "Este tipo de pesquisa é realizado especialmente quando o tema escolhido é pouco explorado e torna-se difícil sobre ele formular hipóteses precisas e operacionalizáveis" (GIL, 1999, p. 43).

Para delinear a pesquisa, adotamos o estudo de caso, cuja proposta foi estudar as ferramentas da Folha.com e a apropriação do público em relação a elas. De acordo com Yin (1981 apud GIL, 1999, p. 73), o estudo de caso é um estudo empírico que tem por objetivo investigar um fenômeno atual dentro de seu contexto de realidade, em que as fronteiras entre o fenômeno e o contexto não estão claramente definidas. Assim, nosso estudo teve o propósito de explorar situações da vida real, perpassadas no ambiente virtual: o desempenho de papéis por parte dos públicos na produção de conteúdo digital 
Estudos em Jornalismo e Mídia - Vol. 9 N I - Janeiro a Junho de 2012 ISSNe 1984-6924

da Folha.com, cujas práticas ainda não estão claramente definidas. Duarte (2009, p. 219) salienta que a preferência ao estudo de caso deve ocorrer quando se pretende examinar eventos contemporâneos, corroborando nossa escolha por esse método.

Para a realização deste estudo de caso utilizamos a técnica da observação nãoparticipante, em que é realizada sem a presença física do pesquisador, no nosso caso por se tratar do meio digital, e sem interação ou qualquer interferência.

Optamos por observar o site do jornal Folha de S. Paulo ${ }^{2}$ em virtude do recente lançamento de uma editoria específica para o público, o 'Painel do Leitor'. As seções do 'Painel do Leitor' foram analisadas individualmente, assim como a atuação dos perfis da Folha de S. Paulo no Twitter e no Facebook. As categorias de análise consideraram: a) o teor do conteúdo de cada seção; b) o tipo de participação do público; c) o nível de interferência editorial (se há produção jornalística junto à produção do público); d) modo de negociação (o discurso do jornal quando da estimulação/participação do público).

Entre os dias 18 e 25 de outubro de 2011 foi realizada a coleta de dados para a investigação, que resultou em um total de 50 matérias, oriundas de todas as seções da editoria.

\section{Cenário da pesquisa}

A Folha.com lançou uma editoria especial para os leitores no final de setembro de 2011 - o 'Painel do Leitor' ${ }^{3}$. A página já existia, mas era uma mera extensão da editoria da versão impressa do noticiário. A reformulação passou a reunir várias ferramentas de interação com o leitor em uma mesma página.

A criação de páginas especiais para a participação do público - como faz também o portal G1, com a editoria 'Vc no G1', e o portal Terra, com o 'Vc Repórter' é uma demonstração da atenção que os veículos de comunicação têm dispensado ultimamente à sua audiência, independentemente da motivação - seja em prol da interatividade ou meros fins comerciais.

O 'Painel' conta com onze seções, as quais apresentaremos a seguir. Cada uma traz uma particularidade de atuação do público, mas basicamente todas versam o 
Estudos em Jornalismo e Mídia - Vol. 9 N I - Janeiro a Junho de 2012 ISSNe 1984-6924

estímulo à participação dos usuários. Assim, o jornalismo digital abre espaço ao jornalismo cidadão, também chamado de colaborativo, participativo.

\section{Envie sua notícia/Colabore com a Folba}

Como indicam os nomes destas duas editorias, o leitor é convidado a colaborar com o conteúdo da Folha.com, enviando relatos, vídeos ou fotos de acontecimentos no Brasil e ao redor do mundo. No entanto, antes de enviar a notícia os públicos entram em uma espécie de negociação com o site, onde os critérios já estão estabelecidos pela Folha. Começa pelo título da página de envio do relato: "Folha.com publica a sua notícia exclusiva". A exclusividade é uma exigência colocada de forma sutil pelo site e que denota seus objetivos não tão sociais e cidadãos, já que é um critério comumente adotado em prol de fins comerciais pelos grupos de comunicação.

Outra negociação é a obrigatoriedade do preenchimento de dados de identificação do leitor que está enviando o conteúdo. Esse requisito é comum no jornalismo open source ou colaborativo, onde o anonimato é visto com desconfiança.

Ao enviar o conteúdo, o leitor deve autorizar sua reprodução e a utilização de seu nome nos créditos, concordando com os termos e condições de envio. Os conteúdos enviados passarão pelo gatekeeping e, depois de editados, abastecerão as seções as quais forem mais apropriadas. Para Aguiar e Barsotti (2011 apud BRAMBILLA, 2006), a filtragem e edição do conteúdo enviado pelos leitores por um profissional, que pode ser um editor, são necessárias. Esse processo é o que legitima o noticiário "sem deixar os interagentes sem voz".

\section{A Cidade é Sua}

Esta seção é um canal de serviço para os leitores. A partir de denúncias e reclamações dos usuários, a equipe de jornalistas produz uma matéria, na qual procura ouvir a outra parte envolvida. O leitor recorre à força e repercussão dos veículos midiáticos na tentativa de solucionar seus impasses, ao passo que alerta outros leitores/consumidores. O benefício, dessa forma, chega em via de mão dupla, pois ao mesmo tempo que o veículo fortalece seu capital social e conquista credibilidade junto 
aos leitores, estes conseguem uma resposta mais rápida, quando não mais eficaz, das empresas envolvidas na reclamação. Ao analisar os meandros do jornalismo cidadão, Abreu (2003, p. 33) afirma que a mídia transformou-se no meio mais eficiente para a população de grandes centros urbanos na luta pela garantia de seus direitos e acesso ao sistema judiciário. Essa função na luta pelos direitos dos cidadãos a partir de suas denúncias é, portanto, concedida pela própria sociedade.

\section{Últimas das Redes Sociais}

Esta seção não é produzida pelos públicos, mas se refere a uma parte dele: os usuários do Twitter e os assuntos de maior repercussão do dia nessa rede. Nas matérias publicadas durante a análise, vários dos assuntos em voga nos Trending Topics (do Brasil, de São Paulo, do Rio de Janeiro e do Mundo) - a lista dos assuntos mais comentados no Twitter - foram relatados e explicados, em geral acompanhados do hiperlink de uma matéria da Folha sobre o assunto. De produtor de conteúdo, o leitor torna-se, aqui, produto de observação e de registro diário. O que os usuários dizem nas redes sociais ganha importância e atenção do jornal. Assim, pode-se dizer que as redes, por vezes, pautam os jornais. Há, na verdade, um interagendamento, pois muito do que consta ali é fruto de agendamento dos veículos de comunicação.

\section{Agenda Folha}

Traz os eventos promovidos pela Folha como sabatinas, debates e bate-papos. Trata-se apenas de uma promoção institucional.

\section{Fale com a Folha}

Apresenta os links para o 'Erramos', o Serviço de Atendimento ao Assinante (SAA) e para contato com o Ombudsman. 


\section{Raio-x: perfil do leitor da Folha}

Trata-se de "um painel detalhado sobre como se informam os brasileiros e sobre quem é o público da Folha nas suas várias plataformas: impressa, on-line, em vídeo, rádio, tablets e smartphones" ${ }^{\prime 4}$. No entanto, os dados divulgados só ajudam a construir uma perspectiva socioeconômica do leitor, assim como o enfoque da matéria, que ressalta a "ultraqualificação" do seu público, denotando, com isso, o intuito essencialmente econômico da pesquisa: "O leitor da Folha nas versões papel e digital está no topo da pirâmide social. No caso do impresso, $41 \%$ fazem parte da classe A, contra 3\% na população em geral.”

Wolf (2001 apud FERNANDES, 2005) explica que embora as empresas de comunicação realizem pesquisas para melhor conhecer o público, os jornalistas raramente o conhecem ou desejam conhecê-lo. Essas pesquisas, assim, mais contribuem para os departamentos de marketing do que para influir nas pautas do jornal.

\section{Comentários}

Essa ferramenta está disponível nas matérias das demais editorias do site, além do 'Painel'. Os usuários podem expor suas opiniões sobre as matérias e reportagens apresentadas e, não obstante, interagir entre si. É frequente um usuário rebater a opinião do outro e/ou questionar determinado conteúdo. Torna-se, de certa forma, um feedback para o jornalista que produziu o texto e, consequentemente, para o veículo.

\section{Twitter e Facebook}

No Twitter, a Folha possui um perfil geral que leva o nome do site (@Folha_com), com pouco mais de 209 mil seguidores, e ainda outros 32 perfis, canais específicos de algumas editorias, segundo a página ${ }^{5}$ da Folha que reúne todos os perfis, muitos deles sem atualização há um bom tempo.

O perfil no Facebook ${ }^{6}$ possui um maior número de "seguidores", mais de 600 mil pessoas "curtiram" a página oficial. Lá, as manchetes divulgadas são comentadas por um número considerável de usuários, que interagem entre si. Nívea Carvalho (2011, p. 112) observa o diferencial dessas redes: 
[...] diferentemente da participação das pessoas nas seções de comentários dos sites - sujeita a uma espécie de admissão, como a feitura de cadastros, e à aprovação de comentários pelo moderador todos com perfis nas redes agora podem entrar. E não mais serem silenciados com bloqueios (a forma mais eficiente de terminar um relacionamento com uma pessoa).

A presença da Folha.com nessas mídias sociais, além de demarcar território virtual, demonstra que o principal objetivo não é a interação e conversação com o usuário, saber suas demandas, mas apenas encontrar um novo ambiente para divulgação de seus conteúdos. Martins (2011, p. 108) reforça a característica conversacional das redes e diz que os veículos devem se atentar a isso. "É preciso responder. Seguidores não são números, são pessoas. Redes sociais são pessoas, não ferramentas”.

\section{Reflexões acerca dos papéis dos públicos}

Considerando o duplo estatuto (receptor/produtor) dos públicos, podemos refletir acerca dos papéis que eles exercem a partir das ferramentas disponíveis no 'Painel do Leitor' e por meio da interação com os perfis da Folha nas mídias sociais:

\section{Jornalista amador}

Por amador, seguimos a definição do novo dicionário Aurélio da língua portuguesa (2004, p. 111), que classifica aquele "que se dedica a uma arte ou ofício por prazer, sem fazer destes um meio de vida". Nesse sentido, considerando também o exercício não-remunerado e, portanto, voluntário, o público assume um papel de jornalista amador no âmbito do jornalismo digital, especificamente no noticiário on-line da Folha de S. Paulo. "Muitos leitores transformaram-se em 'jornalistas', ou seja, qualquer pessoa com acesso à Internet é um potencial jornalista, escritor ou autor" (BARBOSA, 2011, p. 4). Esses jornalistas amadores veem em vários sites de notícia a oportunidade de expor sua produção, que antes ficava restrita aos seus seguidores nas redes sociais ou leitores nos blogs.

[...] se até então o usuário batia na porta de um veículo oferecendo o seu conteúdo para publicação, agora é o veículo que deve correr atrás do usuário em busca de um conteúdo diferenciado e com alto teor de noticiabilidade. Foi o que vimos nos episódios de tremores de terra em São Paulo (2008) e em Brasília (2010), relatados no Twitter antes que qualquer veículo noticiasse. (BRAMBILLA, p. 99-100) 
Barbosa (2011, p. 3) ressalta a importância da colaboração dos usuários. "Eles conhecem a realidade e, muitas vezes, sabem mais sobre determinados assuntos do que os jornalistas". Considerando as limitações das redações em termos de pessoal, contar com a colaboração desses jornalistas em potencial, espalhados por diversos cantos do globo, pode ser importante no registro de acontecimentos inesperados no menor tempo possível.

Em vista da diversidade de características das iniciativas dos "jornalistas amadores", podemos desmembrar vários eixos de atuação destes:

\section{Repórter/Opinador}

As produções “jornalísticas” dos públicos verificadas no 'Painel do Leitor' se caracterizam basicamente por dois tipos, que não raramente estão juntos: o registro dos fatos e a opinião/comentário sobre eles. Quando do registro puro, geralmente é publicado o conteúdo enviado pelo usuário (vídeo ou imagem) com apenas o relato do acontecimento, em alguns casos a contextualização fica por conta de um jornalista profissional. A única seção em que se verificou ao menos um registro isento de opinião foi a seção 'Meu Olhar'. Nas demais abunda o registro aliado à opinião.

Assim, percebemos que a ênfase, até pelos principais destaques verificados, está em saber a opinião do leitor. A grande maioria dos títulos também atribui afirmações, opiniões ou registros aos leitores. São comuns títulos do tipo: "Leitor registra espetáculo em torno do sol por volta do meio-dia em Brasília" e "Acidentes mostram que álcool e direção não combinam, observa leitor de SP”.

Ao investigar a participação do público nas seções específicas para isso nos sites noticiosos brasileiros, Corrêa e Madureira (2010, p. 176) observaram que não há, nos colaboradores, um comprometimento nem estímulo "para apurar informações e realizar cruzamento de fontes, práticas comuns e necessárias à disciplina da checagem de dados". A intervenção da redação no processo, apurando, complementando informações e, quando necessário, conferindo um formato jornalístico, se faz necessária a fim de resguardar a credibilidade do jornal. 


\section{Gatekeeper}

Jim Hall (2001 apud AROSO, 2011) diz que os papéis de gatekeeper e filtro noticioso do jornalismo entraram em risco quando as suas fontes primárias se tornaram acessíveis às audiências (como agências de notícias, notas oficiais etc). Considerando a era digital e a inversão dos fluxos de informação, em que a recepção passa a dispor das mesmas ferramentas que os jornalistas no ambiente on-line, o autor avalia que os públicos assumem um papel de guarda dos portões (Gatekeeper). "A partir do momento em que os leitores se tornam os seus próprios contadores de histórias, o papel de gatekeeper passa, em grande parte, do jornalista para eles".

No 'Painel do Leitor', a seção 'Vi na Web' é um bom exemplo disso. Diante da enorme demanda, o usuário seleciona aquilo que acha mais pertinente dos vídeos que estão na web e encaminha para a Folha. Faz, portanto, uma seleção em meio a uma enorme demanda do que julga mais apropriado ou interessante para publicação.

Na própria produção de notícias o público também exerce, de alguma forma, uma função de editor/gatekeeper. Ao hierarquizar informações, priorizando algumas e descartando outras, ao adotar algum enfoque, ao escolher registrar um acontecimento em detrimento de outro, por exemplo.

A apropriação desse papel por parte dos públicos não chega a ser uma ameaça ao papel do jornalista. Pela análise, percebemos que em razão das limitações técnicas, operacionais e de pessoal da redação, diante da complexidade da sociedade contemporânea e seu ciberespaço, contar com a colaboração dos públicos no processo de gatekeeping pode ser importante para abranger sua cobertura e enriquecer seu conteúdo.

\section{Fonte}

Além de produtores, os públicos também exercem um importante papel: o de fonte, seja de denúncias, pautas ou personagens de reportagens.

Um jornal não é jamais feito sem fontes e nós sabemos que essas fontes são agora muito ativas para propor conteúdos bastante organizados e estruturados. E essas fontes são, em parte, o público do jornal, nós lemos o jornal porque ele se parece conosco, porque nós nos vemos nele, porque nós o produzimos. (RUELLAN, 2011, p. 8) 
Barbosa (2011, p. 3) afirma que os públicos podem ser "importantes fontes de informação, provavelmente mais desinteressadas do que as fontes oficiais, e chamar a atenção para temas não muito retratados pelos jornais e que são interessantes para a audiência". No "Painel do Leitor" as editorias 'A cidade é sua' e 'Pergunta da semana' são algumas das formas em que o papel do público como fonte é explicitado.

A 'Pergunta da semana' é outro instrumento que visa recolher material para a produção de novos conteúdos, seja para abastecer a coluna 'Semana do leitor', seja para enriquecer uma matéria sobre determinado tema. O leitor torna-se fonte de consulta, onde sua opinião ganha relevância.

Na coluna 'Últimas das Redes Sociais', a mídia digital, alimentada sobretudo por leitores, se torna fonte para os jornalistas. A relevância e noticiabilidade, no ambiente dessas mídias, se dão também em virtude da presença de muitas celebridades e autoridades políticas que usam as redes, muitas vezes, para pronunciamentos oficiais e também em razão da repercussão de um fato entre milhares de usuários.

\section{Compartilhador}

Pelas mídias sociais, os públicos podem exercer um importante papel - que para os jornais, em termos econômicos, pode ser o mais interessante: o de distribuir, compartilhar, fazendo circular matérias dos jornais entre seus "amigos/seguidores" nas mídias sociais, possivelmente multiplicando o número de acessos ao disponibilizá-las nesses ambientes. Esse compartilhamento das notícias, no entanto, pode vir acompanhado de um reforço ideológico, apoio, elogios, críticas, contestações ou a mera reprodução do que foi dito. Em contrapartida, fornece aos veículos de comunicação um feedback de suas produções.

\section{Receptor}

Além de todos os papéis possíveis no ciberespaço, os públicos continuam sendo - e alguns exercem apenas este tipo - receptores. Eles abrigam a informação, recebendo-a por essência. Assim, este papel se aplica em todos os aspectos analisados neste trabalho. 
A recepção no ciberespaço, no entanto, tem seu molde próprio. Mesmo que decidam não fazer uso das ferramentas disponíveis para produção de conteúdo ou interação com jornalistas, os usuários, na Internet, estarão numa experiência interativa. Barbero (2006 apud BOAVENTURA, 2009, p. 61) afirma que "o receptor não é mais um simples decodificador da mensagem. Ele é também produtor de sentido." Isso porque a internet permite uma personalização do conteúdo, na qual o indivíduo pode escolher o que vai ver, ler ou ouvir, quando e como.

\section{Considerações finais}

Ao permitir uma democratização nas ferramentas de produção de conteúdo, o ciberespaço reconfigurou as formas de consumo e produção de conteúdo digital, alçando o estatuto do público a uma dicotomia produtora-receptora, tornando-o plural e exigente frente a uma demanda por informação cada vez mais alta. Em contrapartida, a fim de fazer jus à interatividade que, por natureza, define o jornalismo digital e este tanto alardeia, e, ademais, para não perder audiência nem espaço frente à nova demanda, os veículos de comunicação on-line, como a Folha.com, tiveram de abrir espaço para a participação do público, compartilhando a experiência produtiva e gerando novos papéis para a recepção. Neste contexto, relembramos as questões que suscitaram este trabalho: a) Como a Folha.com busca explorar as potencialidades do ciberespaço, desenvolvendo estratégias para a participação do público? b) Como o público interage com essas possibilidades?

Os veículos de comunicação visualizaram um potencial a ser explorado no ciberespaço, sobretudo considerando o perfil dos usuários das mídias sociais interativo, por essência. Não demoraram a marcar território nas novas plataformas digitais. No entanto, muitas das páginas desses veículos em mídias sociais, como os da Folha de S. Paulo, são apenas um receptáculo de conteúdo engessado produzido pelo site, que encontra nas redes um espaço gratuito e em potencial para distribuir essas informações. A interatividade e o desenvolvimento de um relacionamento mais estreito com os usuários quase não são explorados. 
Estudos em Jornalismo e Mídia - Vol. 9 N I - Janeiro a Junho de 2012 ISSNe 1984-6924

Apesar de pouco participativa nas redes sociais, a Folha sabe usar a interatividade dos usuários a seu favor. Consciente do duplo estatuto (produtor-receptor) dos públicos, em que o segundo (produtor) está em franca ascensão, o site de notícias da Folha desenvolveu uma estratégia elaborada para atrair e canalizar todo esse potencial da recepção: criou uma editoria dedicada especialmente aos leitores, o 'Painel do Leitor'. O conteúdo da página é, majoritariamente, produzido pelos usuários, que podem também comentar as produções e interagir com seus pares. Os conteúdos enviados pelos públicos são variados: textos (registro de um fato, crônica, crítica, opinião em forma de artigo etc), fotos, vídeos ou áudios. Ao enviar, o leitor entra em negociação com o site e, caso tenha seu conteúdo aprovado, adquire visibilidade com sua produção que ganha chamada na página inicial do site ou na principal do 'Painel', título e, se o caso, foto de um profissional para ilustrar. Além do caráter mercadológico de captar e fidelizar seus leitores, promovendo uma recepção ativa, a estratégia ainda enriquece o conteúdo do site, pluralizando os discursos e contribuindo para a formação de novos papéis sociais.

A segunda pergunta do trabalho é respondida analisando o desempenho dos públicos em cada ferramenta oferecida pela Folha.com. As situações de interação descritas nos levaram a identificar os papéis sociais adotados, reforçando o caráter identitário multifacetado dos públicos no ciberespaço. O conceito de público, assim, excede as limitações de uma mera recepção e confirma seu caráter plural, elevando-se a um nível mais profundo, como afirma Tredan (2011).

Ao mesmo tempo em que se complexificam e ratificam sua identidade múltipla e instável, os públicos, apropriando-se dessas estratégias como as da Folha.com, não apenas tornam-se parceiros como aproximam-se dos veículos de comunicação fornecendo um feedback pontual, o que pode ser benéfico para o jornalismo, que há muito é acusado de não conhecer seu público e nem o quer. O estreitamento de laços é inevitável.

Por fim, consideramos que as possibilidades de atuação ativa dos usuários no ciberespaço são de um nível historicamente sem precedente e sem volta. Se os canais de serviço, como as editorias específicas para a audiência, não forem mais úteis, não 
seguirem à demanda dos públicos ou ainda se não oferecerem voz de modo efetivo, as mídias sociais, que deram início ao processo, tendem a acolher essa demanda e satisfazer o ativismo da recepção. O jornalismo, no entanto, poderá perder relevância.

\section{Referências}

ABREU, Alzira Alves. "Jornalismo Cidadão". Biblioteca Digital da Fundação Getúlio Vargas. São Paulo, 2003. Disponível em: < http://bibliotecadigital.fgv.br/ojs/index.php/reh/article/view/2185/1324> Acesso em: 20 set. 2011.

AROSO, Inês Mendes Moreira. "A Internet e o novo papel do jornalista". Biblioteca on-line de ciências da comunicação. Disponível em <http://www.bocc.ubi.pt/pag/aroso-ines-internet-jornalista.html $>$ Acesso em 21 out. 2011.

BARBOSA, Elisabete. "Jornalistas e público: novas funções no ambiente online". Labcom. Portugal, 2011.Disponível em: <http://www.labcom.ubi.pt/agoranet/02/barbosa-elisabete-jornalistas-publico.pdf $>$ Acesso em: 5 out. 2011.

BOAVENTURA, Katrine Tokarski. "Recepção e Estudos Culturais: uma relação pouco discutida". Dissertação de Mestrado. Programa de Pós-Graduação em Comunicação da Universidade de Brasília, 2009. Disponível em < http://bdtd.bce.unb.br/tedesimplificado/tde_busca/arquivo.php? codArquivo=5009 $>$ Acesso em 20 out. 2011.

BRAMBILLA, Ana. “Jornalismo”. In: BRAMBILLA, Ana (org.). Para entender as mídias sociais. 2011, p. 97-100. Disponível em: <http://paraentenderasmidiassociais.blogspot.com>. Acesso: em 10 de out. 2011.

CARVALHO, Nívia. "Relacionamento com o leitor". In: BRAMBILLA, Ana (org.). Para entender as mídias sociais. 2011, p. 111-113. Disponível em: <http://paraentenderasmidiassociais.blogspot.com>. Acesso: em 10 de out. 2011.

CORREA, Elizabeth Saad; MADUREIRA, Francisco. "Jornalista cidadão ou fonte de informação: estudo exploratório do papel do público no jornalismo participativo dos grandes portais brasileiros". Estudos em Comunicação, nº , Volume 1, 2010. Disponível em < http://www.ec.ubi.pt/ec/07/pdf/correajornalista.pdf> Acesso em 19 out 2011.

DUARTE, Jorge. Entrevista em profundidade. In: DUARTE, Jorge; BARROS, Antonio (org.). Métodos e Técnicas de Pesquisa em Comunicação. São Paulo: Atlas, 2009, p. 62 - 83.

FERNANDES, Juliana de Brum. "Leitor imaginado: Investigando a imagem que os produtores possuem do leitor". Comunicação \& Informação, Goiânia, V. 8, nº 1, p. 39-46, 2005.

GIL, Antonio Carlos. Métodos e técnicas de pesquisa social. 5 ed. São Paulo: Atlas, 1999.

LEMOS, André. Cibercultura: Tecnologia e vida social contemporânea. Porto Alegre: Sulina, 2010.

LÉVY, Pierre. Cibercultura. São Paulo: Editora 34, 1999. 
MARTINS, Rodrigo. "Relevância”. In: BRAMBILLA, Ana (org.). Para entender as mídias sociais. 2011, p. 107-110. Disponível em: <http://paraentenderasmidiassociais.blogspot.com>. Acesso: em 10 de out. 2011.

MORAES, Francilaine Munhoz. "Da platéia ao palco: Reflexão sobre as Mudanças nos Papéis dos Públicos". In: CONGRESSO BRASILEIRO DE CIÊNCIAS DA COMUNICAÇÃO, 33, 2010, Caxias do Sul. Anais... São Paulo: Intercom, 2010, disponível em:

$<$ http://www.intercom.org.br/papers/nacionais/2010/resumos/R5-2557-1.pdf>. Acesso em: 20 set. 2011.

PEREIRA, Fábio Henrique; ADGHIRNI, Zélia Leal. "O jornalismo em tempo de mudanças estruturais". Intexto, Porto Alegre: UFRGS, v. 1, n. 24, p. 38-57, jan/jun 2011. Disponível em: $<$ http://seer.ufrgs.br/intexto/article/view/19208/12362>. Acesso em: 10 set. 2011.

ROCHA, Liana Vidigal. Liana Vidigal. "Mudanças no fazer jornalístico online? Aspectos das reportagens do portal de notícias G1”. In: COLÓQUIO INTERNACIONAL MUDANÇAS ESTRUTURAIS NO JORNALISMO - MEJOR, 1, 2011a Brasília. Anais... Brasília, Programa de Pós-graduação em Comunicação da UnB, 2011a, p. 191-200. Disponível em:

<http://www.mejor.com.br/index.php/mejor2011/MEJOR2011/paper/view/66>. Acesso em: 04 set. 2011.

RUELLAN, Denis. "Corte e Costura do Jornalismo”. Líbero, v. 9, n. 18, 2006, p. 31-40. Disponível em: $<$ http://www.revistas.univerciencia.org/index.php/libero/article/viewArticle/4619>. Acesso em: 10 ago. 2011.

TREDAN, Olivier. “A construção dos públicos na internet, dos grupos de pares às novas legitimidades culturais". ALCEU, v. 11, n.22, p. 5-25, jan./jun. 2011. Disponível em: < http://revistaalceu.com.pucrio.br/media/Artigo1\%20OLivier\%20Tredan\%20-\%20pp5-25.pdf >. Acesso em: 05 de set. de 2011. 
${ }^{1}$ Disponível em: http://www.ibope.com.br/calandraWeb/servlet/CalandraRedirect?

temp=6\&proj=PortalIBOPE\&pub=T\&nome=home_materia\&db=caldb\&docid=C2A2CAE41B62E75E83257907000EC04F

${ }^{2}$ www.folha.com.br

${ }^{3}$ http://www.folha.com.br/paineldoleitor

4 “Raio-x do leitor": http:/www1.folha.uol.com.br/paineldoleitor/991055-leitor-da-folha-e-ultraqualificado-mostra-pesquisa.shtml

${ }^{5}$ Disponível em: http://www1.folha.uol.com.br/twittersdafolha

${ }^{6} \mathrm{http}: / /$ www.facebook.com/folhadesp, 